\title{
LOCAL PERCEPTIONS OF CLIMATE CHANGE IMPACTS AND MIGRATION PATTERNS IN MALÉ, MALDIVES
}

\begin{abstract}
For the last few decades, Maldives has been seen as being at the forefront of addressing climate change impacts. The low elevation of the islands makes them vulnerable to slow-onset hazards, such as coastal erosion, sea-level rise, salinity intrusion, and change in monsoon patterns and hence rainfall. Consequently, migration has long been discussed as an adaptation strategy for the population. This study covers outcomes from our field research conducted among islanders in Malé, the capital of Maldives, in 2013. It contributes empirical evidence toward understanding complex relations among environmental challenges, climate change, and migration. We set up two main research questions. The first question explored islanders' perceptions of impacts of climatic variability in recent years and possible impacts of future climate change. The second question probed whether out-migration from the islands might be considered to be an adaptation strategy and whether the islanders were willing to move outside Maldives due to projected climate change impacts. We conducted our field research in the capital Malé and nearby residential islands, using quantitative questionnaires with local respondents $(\mathrm{N}=347)$. Our results suggest that, besides a set of actually experienced environmental and climate challenges, slow-onset climate change impacts such as sea-level rise are perceived as being one of the key factors affecting Maldivian society and livelihoods. More then $50 \%$ of respondents perceive future sea-level rise to be a serious challenge at the national level and they accept that migration from islands to other countries might be a potential option. Conversely, from the individual perspective, sea-level rise is not perceived by the local population as being one of their own important challenges. The reason is that many other factorscultural, religious, economic, and social-play an important role in decision-making about migrating or not.
\end{abstract}

Key words: climate change impacts, Maldives, islanders, risk management, environmental inequality, adaptation, migration, quantitative survey

\section{Introduction}

For over 25 years, the low-lying archipelago of Maldives in the Indian Ocean has been recognised as sitting at the forefront of being vulnerable to and addressing climate change impacts, notably coastal erosion, sea-level rise, salinity intrusion, and changes in monsoon patterns leading to floods and droughts (Fulu 2007; Ghina 2003; IOM 2015; Kothari 2014; Sathiendrakumar 1996; Shaig 2006; World Bank 2010). The country was the site of the Small States Conference on Sea Level Rise which ran from 14-18 November 1989 ending with the Malé Declaration on Global Warming and Sea Level Rise. In the run-up to this meeting, UNEP had launched the Ocean and Coastal Areas Programme Activity Centre (OCA/PAC) to assess potential impacts of climate change and to assist national governments in identifying and implementing sustainable policy options and adaptation measures.

Maldives received special attention as an in-depth case study, with Pernetta and Sestini (1989) identifying several key environmental issues, including climate change risks. Since then, these problems and attention to them have been intensifying (Alexander and Mercer 2012; Arnall and Kothari 2015; Baldacchino and Kelman 2014; Fulu 2007; Ghina 2003; Kothari 2014; MHAHE 2001; Sathiendrakumar 1996; Shaig 2006). In particular, the islands display unstable morphology 
shown by the islands' sizes, shapes, elevations, and positions on reef platforms changing over time (Fulu 2007; Ghina 2003; MEEW 2007; Shaig 2006). According to IPCC (2013-2014), sea-level rise projections are $0.3-1.0 \mathrm{~m}$ globally by 2100 over a range of emission scenarios. Such sea-level rise would significantly damage Maldives' economy, particularly the tourism and fishing sectors on which it relies; e.g., the direct contribution of the travel and tourism sector to GDP in 2013 was $48 \%$ which rises to $95 \%$ when indirect effects such as supply chains are considered (WTTC 2014).

Yet island countries - not just Maldives, but many others examined in the literature - display not only vulnerability to challenges including climate change impacts, but also ways of dealing with those impacts (e.g. Gaillard 2007; Lewis 1999; Lewis 2009; Spillius 1957). In implementing adaptation measures, human migration is frequently viewed as a potential strategy, particularly in the context of other factors such as development aid and remittances (Felli and Castree 2012; Foresight 2011; King and Connell 1999; Lewis 1999). In-country migration and resettlement schemes have been common trends over the last several decades in many small islands in the Pacific and Indian Oceans (Bedford and Hugo 2012; Mimura et al. 2007).

In fact, islanders have always migrated for livelihood, social, environmental, security, and other reasons (Bedford and Hugo 2012; Kelman et al. 2015; King and Connell 1999). There has always been a diversity of migration typologies; for instance, for a compilation of environmental migration typologies, see Stojanov et al. (2014). As the relationship between climate change and migration receives increasing attention (Black et al. 2011b; Felli and Castree 2012; Foresight 2011; Myers 1993; Piguet 2008), it is becoming clearer that one single factor is rarely a sufficient reason for migrating. Migration causes are usually multi-faceted, with climate change adding to already increasing levels and complexities of population mobility (de Sherbinin et al. 2011; Felli and Castree 2012; Foresight 2011; Hugo 2011).

In order to understand the scope and impact of climate change on mobility choices, empirical studies examining motivations for migration have been increasing, aiming to disaggregate the factors and to provide empirical evidence regarding migrants' perceptions and explanations for their migration choices. Examples are these focusing on migration within and from drought-affected areas (Henry et al. 2004; Rain 1999); migration-related interests in the context of projected sealevel rise from small island communities (Kelman 2015; Kothari 2014); and migration responses to floods and storms (de Sherbinin et al. 2011; McLeman and Hunter 2010). Often, terms such as "climate refugees" or "climate change refugees" are used, but neither phrase fits robustly into a scientific framework and they have been criticized as being inadequate, politically motivated, and artificially constructed (Bettini 2013; Hartmann 2010; Kelman 2015; Nicholson 2014). Moreover, some authors point out that hazards related to climate change affecting islands are being emphasised too much, so that climate change distracts from other development issues (Kelman 2014).

Consequently, views on migration as adaptation differ. Some authors (Alscher 2011; Black et al. 2011a; Foresight 2011; Martin et al. 2014; McLeman and Smit 2006) accept this concept as a typical, local strategy to deal with climate change. Others (Bettini 2014; Felli and Castree 2012; Kelman 2015; Kelman et al. 2015) explore wider implications for people affected by climate change as well as uncritical assumptions of "climate migration" and of "migration as adaptation". Banerjee, Black and Kniveton (2014) suggest that displacement of entire communities occurs as a last resort once all other adaptation possibilities have been exhausted. Foresight (2011) postulated that facilitating migration because of environmental change might broaden the opportunities and maximise the benefits from the migration process. The narrative of migration as an adaptation strategy has many parallels with the migration and development nexus and the debate over the conditions during which migration may provide a route out of poverty (Banerjee, Black and Kniveton 2014). 
Much of this debate takes place within the academic literature at a conceptual level. Fewer studies examine perspectives and perceptions of those who have to, or who are expected to, make migration-related choices. This study examines local perceptions of environmental challenges facing Maldivians in terms of projected climate change impacts with migration as a potential adaptation strategy.

The next section briefly describes Maldives' environment and geography, followed by a section describing potential adaptation strategies for Maldives, including migration as a possibility. Then, the core of this study is presented, being empirical research with quantitative analysis of local perceptions of environmental change, including adaptation measures with particular attention devoted to migration. The final section provides wider reflections and conclusions.

\section{Environment and geography of Maldives}

Maldives (Fig. 1) comprises an archipelago of 1,190 islands just south of India, grouped into 26 low-lying coral atolls. Around 200 islands are permanently inhabited and 80 more are used as tourist resorts. The land area totals only $298 \mathrm{~km}^{2}$, with no island larger than $10 \mathrm{~km}^{2}$. Over $80 \%$ of the country sits less than 1 metre above sea level (MEEW 2007; Pernetta and Sestini 1989; Republic of Maldives 2010; World Bank 2007). In Maldives, about 10\% of the land is occupied by agricultural/cultivated land, $3 \%$ by forested land, 3\% by pastures (MEE 2011). The soil is thin and of poor quality, being a maximum of about 20 centimetres deep and not too fertile, while often containing rock and sand. It is alkaline due to an excess of calcium from coral rock and sand.

\section{Insert Figure 1.}

\section{Fig. 1. Maldives}

Maldives has a tropical climate, with the air temperature generally varying from $23-31^{\circ} \mathrm{C}$ and an annual mean temperature of $28^{\circ} \mathrm{C}$. Weather is dominated by the two monsoon periods, the SW monsoon from May to November and the NE monsoon from January to March. Average annual precipitation varies regionally and increases from north to south, with the northern atolls receiving on average approximately $1,700 \mathrm{~mm} /$ year and the southern atolls receiving on average approximately 2,350 mm/year (Bailey, Khalil and Chatikavanij 2015). Precipitation has great interannual variability, although the wettest months tend to be May, August, September, and December, with the driest being January to April; overall humidity ranges from 75-83\% (MEEW 2007; Pernetta and Sestini 1989).

A few islands have small lakes, but the main freshwater resource is in thin freshwater lenses underneath the land. These freshwater lenses are often heavily depleted and contaminated, as in the capital city of Malé, and much freshwater was salinized during the 2004 tsunami. Maldives can no longer rely on these freshwater lenses to satisfy their freshwater needs, due to increasing demands from population growth, more saltwater intrusion, increasing demand per capita including from tourism, and rising pollution of groundwater from sewage, industrial effluent, and poor agricultural practices (Bailey, Khalil and Chatikavanij 2015; Basu and Shaw 2013; Ibrahim, Bari and Miles 2002).

Until the 1970's, Maldives' economy was rather isolated and was based on fishing, shipping, and coconut cultivation. It changed after the advent of tourism, which has been stimulating new economic activities and investment. The economy remains focused on tourism and fishing, meaning that together with low agricultural production, it is highly dependent on imports of goods and services, with the economy exhibiting large fluctuations. For example, while the economy grew by 
$19.6 \%$ in 2006, it dropped $3.6 \%$ in 2009 due to the world financial crisis and hence reduced tourist numbers. But in 2010, it increased by $7.1 \%$. Then in 2013, economic growth was $3.7 \%$ (World Bank 2014). Recently, the Government of Maldives has been striving to develop new economic sectors, such as off-port shipping services, information technology, and financial services in order to reduce Maldives' current reliance on tourism (World Bank 2014).

The country is also burdened by its high level of central government debt. While at the beginning of the century, the ratio of debt to GDP remained quite stable at $40 \%$ of GDP, after 2008, it grew rapidly and in 2011 was $73.5 \%$ of GDP (World Bank 2015). Recently, the World Bank (2014) classed Maldives as at "high risk" of debt distress because in 2014, the debt was around $86 \%$ of GDP and debt dynamics are projected to deteriorate further.

To sum up, Maldives exemplifies the challenges and opportunities facing small island states under environmental change (Alexander and Mercer 2012; Dolman 1985; Hay 2013; Julca and Paddison 2010; Kelman 2014; Lewis 1999). The distribution of the population across many islands burdens the public budget for infrastructure, transport, health care, social services, and education while providing advantages for tourism, culture, and quality of life. These baseline characteristics remain as climate change increasingly affects the country.

\section{Climate change and adaptation in Maldives}

\subsection{Adaptation strategies}

Adaptation is defined as "the process of adjustment to actual or expected climate and its effects" (IPCC 2013-2014, Glossary, 1) and is applied to Maldives in the Strategic National Action Plan for Disaster Risk Reduction and Climate Change Adaptation (SNAP) which aims to empower four strategic areas from 2010-2020 for climate change risk (Republic of Maldives 2010):

(i) an enabling environment towards good governance;

(ii) empowered and capable communities; and

(iii) communities with access to technology, knowledge, other resources; and

(iv) risk-sensitive regional and local development.

As shown in Table 1 for the coasts, hard and soft adaptation measures are often distinguished. Soft measures tend to be smaller-scale, less capital-intensive approaches including ecosystem-based adaptation such as planting mangroves and protecting coastal vegetation, compared to hard measures which tend to be coastal engineering and building structures such as sea walls (Sovacool 2012).

Insert Table 1.

\section{Table 1: Examples of hard and soft adaptation measures for coasts}

But which measures are best suited to offer a sustainable future for Maldives? Sovacool (2012) suggests that the heterogeneity and diversity of Maldives means that a single solution does not exist. The main dilemma is cost, in terms of who will pay for the necessary measures, including community consultations to ensure that the people's ideas, views, and expertise are incorporated. Alexander and Mercer (2012) examine a community-based approach to ensure that options and decisions are thoroughly investigated and that the community has a strong say in the decisionmaking process and ultimate outcome. The presumption is that donors external to Maldives would need to fund the work, leading to power asymmetries between Maldivians deciding what they want 
and non-Maldivian donors potentially having their own preferences.

So far, at the national level, several programmes and projects have been pursued, with SNAP (Republic of Maldives 2010) mentioned above. The National Adaptation Programme of Action (MEEW 2007) also set up several key areas of climate change impacts to be addressed. The first area deals with environmental issues such as land loss, beach erosion, threats to coral reef biodiversity and threats to freshwater and rainwater. The second area covers threats to infrastructure such as critical infrastructure, settlements, and tourist resorts. The third area relates to agriculture, water availability, and food security. These key areas are interconnected. For example, threats to freshwater sources influence agriculture, water availability, food security, and human health. Adaptation approaches must be long-term and connected to each other, covering environmental, economic, and social issues.

Maldives also has its Safer Island Strategy and Safer Island Development Program; the term "safe islands" refers to Maldives' larger islands which will theoretically be adapted to climate change through reclamation and other, mainly hard, measures so that people can migrate there (Islam, Hove and Parry 2011). Concerns about this adaptation measure include the impacts on the local environment, especially biodiversity, and the sensitivity of relocation as a topic, especially the voluntariness of moving. In 2010, another project called Integration of Climate Change Risks into the Maldives Safer Island Development Programme reflected transitions to and changes of adaptation frameworks, focusing on soft adaptation strategies, such as empowering local communities, using natural vegetation, and decentralizing decision-making (Elrick-Barr, Glavonic and Kay 2015; GEF 2009; Sovacool 2012).

Sovacool (2012) argues that future climate change threats and some economic and development motivations may be among the strongest drivers for preferring hard solutions, especially relocating people to the new artificial islands (called "designer islands"). Hulhumale is the most visible example. This island is set to be inhabited by 100,000 new inhabitants by 2030. Another example is Dhuvaafaru in Raa Atoll, which was re-settled in 2009 by residents from Kandolhudhoo which was destroyed by the 2004 tsunami (Sovacool 2012).

Settlements and infrastructure have no choice but to be located on low-lying land near the shoreline, because that is all the country has. Thus, they are affected by impacts exacerbated by sea-level rise, including inundation, beach erosion, storm surges, and high waves. According to Shaig (2006), more than $42 \%$ of the population and $47 \%$ of all housing structures are within 100 metres of the coastline. Localised human activities contribute to the challenges, with specific problems including high population and housing densities, poor infrastructure, and devastation of beach vegetation. Several responses have been implemented, starting with individual voluntary migration and resettlement projects (which increased after the 2004 tsunami destroyed several Maldivian communities, e.g. Pardasani 2006), and land reclamation. The largest reclamation project (Shaig 2006) is Hulhumalé, a 100\% reclaimed island approximately $1.89 \mathrm{~km}^{2}$ in area. Other examples of partially reclaimed islands are Male $\left(0.82 \mathrm{~km}^{2}, 41 \%\right.$ of the current land area is reclaimed), Maamigili $\left(0.8 \mathrm{~km}^{2}, 51 \%\right.$ of the current land area is reclaimed), and Hulhule which has the international airport $\left(0.76 \mathrm{~km}^{2}, 58 \%\right.$ of the current land area is reclaimed $)$.

Land reclamation as an example of a large-scale adaptation measure may exacerbate problems and contribute to environmental harm. Sovacool (2012), Perneta and Sestini (1989), and Perneta (1992) mention coastal dredging for construction of harbours and surrounding infrastructure such as protecting wall, breakwaters, and jetties. Creating an artificial environment can potentially contribute to the destruction of surrounding coral reefs, burying original lagoons and interrupting sediment movements. Another adaptation option remains, that of out-migration, which is further developed in section 3.2. 


\subsection{Out-migration as adaptation?}

Besides land reclamation as an adaptation option or staying, out-migration as an adaptation option for leaving is discussed. Some authors point out positive consequences of migration related to climate changes. Birk and Rasmussen (2014), Black et al. (2011a), and Tacoli (2009) discuss livelihood diversification, environmental pressures easing at home, and opportunities increasing for income availability - all of which support climate change adaptation. McLeman and Smit (2006) consider human migration as a reasonable response to environmental risk exposure, such as climate change. According to King et al. (2014), relocation is a strategy available to some as part of an extensive range of responses to extreme weather, but unsupported resettlement is not always an option for reasons such as family commitment, livelihood opportunities, and financial constraints.

In fact, while many islanders have always used migration as a livelihoods and adaptation strategy, some typically undertake migration as a last resort when all other possibilities have been exhausted (Bedford and Hugo 2012; King et al. 2014; King and Connell 1999). Farbotko (2005) indicates for Tuvalu that non-migration adaptation strategies are more significant for island peoples faced with climate change than relocation and mitigation initiatives in the future. Notwithstanding the cases where communities have been forced to move due to climate change only, Kelman et al. (2015) point out that climate change does not immediately or substantively change mobility and nonmobility choices of many living in low-lying island communities.

Arnall and Kothari (2015) revealed some discrepancies among Maldivian attitudes to links between climate change and migration. They showed that many Maldivians, called "non-elites" (ordinary people) by the authors, did not see sea-level rise as being a sufficient reason to migrate. Conversely, elites were more concerned. Arnall and Kothari (2015) also noted that older interviewees preferred to stay where they were, but were also relatively open to the prospect of relocating, provided that the national government covered the costs of resettlement in full. In contrast, many younger interviewees viewed migration induced by climate change as a potential opportunity to secure a better life elsewhere.

Meanwhile, Kumar (2014) does not consider migration from Indian Ocean islands as a solution to natural resource shortages and overpopulation. He applies the same judgement to planned relocation of whole communities elsewhere on purchased land. He argues that relocated inhabitants would not have electoral rights and would lose their culture and language, while potentially contributing to religious conflicts.

Within this context, is migration as adaptation suitable for Maldivians? For the moment, the situation is not urgent because migration as adaptation may emerge from slow environmental degradation linked to climate change, but it could nonetheless change any day due to extreme weather or other sudden changes (Kelman 2015). Additionally, not all the islanders depend entirely on environmental resources directly, because of the large volume of imports (including bottled water) and the tourism-based livelihoods. Migration as adaptation is possible, but not necessarily essential for Maldivians, although it is important to consider whether or not internal migration should or could suffice for long-term adaptation.

\section{Methodology}

This study focuses on Maldivian perspectives on climate change impacts and migration patterns, examining links (or lack of links) between the two phenomena. The two main questions investigated are: 
(1) How do local residents perceive the current and potential future impacts of climate change?

(2) How might migration be considered or not considered as a potential climate change adaptation strategy?

The respondent sample is taken from the capital city, the island of Malé, and the nearby residential islands of Villingili and Hulhumale (Fig. 2). No assumption is made that these results are generalizable beyond Maldives, particularly given the cultural diversity of other island countries which might experience similar climate change impacts to those in Maldives, especially the consequences of sea-level rise. Instead, by focusing on Maldives here, we follow the call by Upadhyay et al. (2015) for contextualisation when investigating climate change and migration links. By selecting a specified geographic area for a particular study, this call has been met by the many others studies of islands, climate change, and migration including for the Marshall Islands (RudiakGould 2013) and Tuvalu (Shen and Gemenne 2011).

Insert Figure 2.

\section{Fig. 2. North Malé Atoll and detail of Malé, Villingili, Hulhumalé islands}

Our questionnaires focused on respondents' perceptions of environmental threats, climate change, livelihood conditions, and migration intentions and patterns using quantitative closed questions. Four main question clusters were used:

(i) household and demographic characteristics;

(ii) current living conditions;

(iii) perceptions of socio-economic and environmental changes; and

(iv) migration patterns, tendencies, and perceptions of migration due to future sea-level rise impacts.

We completed 347 questionnaires from August-November 2013 via face-to-face interviews. The researcher asked a household member on the street or in any public space to participate and the researcher completed the questionnaire with the respondent. This method ensured the possibilities of explaining those questions which were not clear to respondents, and obtaining additional responses, personal opinions, and other pertinent information related to each specific response. The respondents were guaranteed anonymity and confidentiality.

For selecting respondents, we aimed for as wide a range of age, education, and employment as possible, but only respondents aged eighteen years or older. Because of the geographical focus of the survey, the sample is not representative of the population of Maldives as a whole. We report standard logit models (logistic regression) for statistical analysis (Cameron and Trivedi 2005).

\section{Findings and discussion}

\subsection{Perceptions and understandings of environmental change impacts}

The questionnaire investigated respondents' experience with extreme weather conditions and their ways of dealing with these, and their experiences of any changes in weather patterns. This section addresses these perceptions if weather and climate for all respondents. Respondents were given a questionnaire investigating respondents' experience with extreme weather, their responses, and their experiences with any changes in weather patterns.

More than $60 \%$ of all respondents had experienced extreme natural hazards in the past, the majority of them referring to the 2004 tsunami, while recognizing that the tsunami was not linked to climate 
change. To deal with such experiences, of the respondents who had experienced extreme natural hazards, almost $17 \%$ mentioned house reconstruction and $13 \%$ mentioned migration. Other structural measures (e.g. sea walls and drainage systems) were mentioned by $11 \%$ of respondents. More than $40 \%$ of respondents did not suggest any measures. The rest of the respondents mentioned other approaches including government subsidies and international aid. While not implying that climate change causes or would cause tsunamis, the respondents tended to assume that climate change impacts would be similar to their tsunami experience.

In the context of climate variability and weather changes, $71 \%$ of respondents had observed some shifts and changes in weather patterns within the past 10-15 years. Just $8 \%$ had not observed any changes, while the remainder had not noticed. From the entire sample of respondents, 53\% perceived summer monsoons to be hotter today, and $31 \%$ perceived them to be coming sooner. Meanwhile, winter monsoons were hotter (48\%) with less rain (38\%). From the 247 respondents who observed some changes in weather within the previous $10-15$ years, $31 \%$ were members of a household in which at least one person had a university degree, $24 \%$ came from households including at least one person with a college diploma, and 15\% came from households with only secondary school education.

Table 2 shows that $37 \%$ of all respondents worried about environmental challenges, such as lack of space for living and population growth $(18 \%)$, climate variability or dry weather and water shortages $(9 \%)$, and impacts of sea-level rise and soil erosion $(7 \%)$. The perception of other future challenges such as job availability (10\%), higher crime rates (4\%), political instability and conflicts $(5 \%)$, and low quality of healthcare and education (4\%) were not considered to be as serious as environmental concerns.

This outcome is likely to be due to the high awareness and political priority of environmental topics, as well as the strong international perception of Maldives as being highly impacted by climate change, to the degree that Maldives has become an icon for these impacts. Nevertheless, the environmental concerns highlighted have direct impact on day-to-day lives, whereas the other topics do not necessarily, to the same level. For example, water shortages and coastal erosion are environmental concerns that directly impact day-to-day life on small islands. Lack of space due to the high population density cannot be escaped, so it is a frequent topic of discussion in the streets and at higher political levels.

Meanwhile, Maldives has suffered from political instability for several years leading to street violence and arrests for treason. Yet rates of petty crime and day-to-day criminal acts are low. Additionally, some violations of human rights such as domestic, sexual, and gender-based violence, while fluctuating substantially in recent years (Fulu 2014), might not always be assumed to be a crime in Maldivian (or many Western) societies, whether or not the law forbids them. Consequently, crime rates may not be seen as a major concern, in line with respondents' views. The low rates of concern for political instability and health/education quality are surprising, but the location of the interviews might account for this result. Those living in Malé have access to the best health care and education in the country, so locally, this topic might be of less concern. Similarly, while national politics is highly contentious in the country and is always a topic for discussions in the street, its impact on day-to-day life is less than some of the other concerns raised.

Insert Table 2.

Table 2: Respondents' perceptions of challenges

\subsection{Migration patterns - descriptive analyses}

From the perspective of respondents who have already been internal migrants, improved education, 
livelihoods, and living conditions are the decisive factors for migrating, mentioned by $44 \%$ of respondents who moved from other islands to Malé. Just $2 \%$ of these respondents suggested poor environmental conditions or natural hazards. Socio-economic factors dominate internal migration decisions.

$49 \%$ of respondents plan to move abroad, migrating either temporarily or permanently. The main reasons are seeking improved health care, education, and living conditions (26\%) followed by family reasons, nationality, and religion (20\%). Environmental reasons - specifically sea-level rise and soil erosion, climate variability, overpopulation, and lack of living space-were mentioned by $13 \%$ of respondents. Prevailing factors motivating the respondents to move away remain socioeconomic. On the other hand, environmental factors play a more important role in respondents' decision-making to leave Maldives compared to internal migration to Malé.

Just $10 \%$ of respondents from households with university degrees mentioned these environmental reasons, while $13 \%$ with college diplomas and $14 \%$ with only secondary education mentioned environmental reasons. Nobody mentioned dry weather or water shortages as a possible reason for migrating. Household education level appears to make little difference to views of environmental reasons for migrating.

Little academic literature exists on internal migration within Maldives. One of the most detailed studies (Sathiendrakumar and Tisdell 1987) is also rather outdated, being published before climate change had such a large political influence and highlighting livelihood reasons as the principal factor for internal migration. Kothari (2014) provides an historical account of central government policies regarding internal migration in Maldives. For decades, the government has been trying to consolidate the population from outer islands to a small number of islands on which larger communities would be built. Originally, the government's reason for population consolidation was given as economic sustainability and provision of social services. Now, the government's reason for population consolidation is given as climate change. Consequently, the top-down discourse for internal migration has been changing, but so far, the consolidation policy has not been implemented. In terms of the wider literature on islander mobility (e.g. Baldacchino 2007; Guan and McElroy 2012; Kelman et al. 2015, King and Connell 1999), internal migration-primarily from outer islands or rural areas to the capital-is common, with the main reasons being better education, livelihoods, and living conditions, exactly as for Maldives. The data here provide new insights from Maldives, matching well with previous studies on islander mobility.

Respondents mentioned various preferred destinations and regions for migrating. We defined clusters to evaluate the main destination regions, differentiated geographically and economically. Cluster 1 consists of more economically developed countries, but rather distant from Maldives, such as the European Union and the USA. Cluster 2 comprises Asian countries located comparatively close geographically and culturally to Maldives, mainly India, Sri Lanka, Malaysia, and Indonesia. Cluster 3 consists of two more economically developed countries, Australia and New Zealand. Cluster 4 indicates internal migration within Maldives.

Respondents prefer to migrate anywhere (19\%) and to relatively close Asian countries (20\%) (Table $3)$. Of the more developed countries, respondents prefer Cluster $3(19 \%)$ followed by Cluster 1 (9\%) - but the USA was mentioned by only two household members, presumably because the country is far from Maldives and popular entertainment depictions of the country tend to demonstrate vast cultural differences from Maldives. The pattern of response is that locations nearer, and perceived to be more culturally similar to Maldives, are preferred migration destinations, which is to be expected.

\section{Insert Table 3.}


Table 3: Preferred migration destinations by destination cluster and education level

Countries relatively close to Maldives prevail as the main out-migration destinations (Table 3). Respondents prefer to move to Australia (17\%), Malaysia (8\%), Sri Lanka (4\%), and India (3\%). The sums from Table 3 do not correspond because some respondents mentioned more than one destination from different clusters.

When we compare levels of education in the household and migration destination, we find some differences. About $32 \%$ of respondents from households with university education prefer migration to another Maldivian island (10\%) or to Asia (22\%), especially to Malaysia (9\%), Sri Lanka (4\%), and India (3\%). Meanwhile, more than $18 \%$ of these respondents prefer to move to Australia. As for respondents from households with only secondary school education level, they prefer to migrate to other Maldivian islands (22\%) or move to other Asian countries such as India (4\%), Malaysia (9\%), and Sri Lanka (4\%) - and to Australia (15\%), New Zealand (2\%), and the USA (1\%) (Table 3).

17 respondents who chose environmental reasons for migrating prefer to move to Australia and New Zealand (Table 4). Meanwhile, preferred destinations of respondents choosing social and economic reasons are almost equal among three clusters (Europe-USA, Asia, and Australia-New Zealand).

Insert Table 4.

Table 4: Reasons for migrating according to destination cluster

Table 5 provides respondents' opinions on out-migration of the whole Maldivian population due to sea-level rise in the future. Just under half of the respondents suggested future out-migration as a potential, or necessary survival strategy, with most of this group stating that out-migration will be necessary. A handful considered it to be a future possibility. Nearly one quarter of respondents did not agree, either because they do not believe that it could happen (the majority view) or that adaptation would be possible (a minority view).

Despite the prevalence of the external construction that Maldivians will need to be evacuated due to sea-level rise, internal views are more varied but less nonchalant than other examinations (Arnall and Kothari 2015; Kothari 2014). The existence of a substantial minority countering the external, top-down constructions of inevitably disappearing islands matches findings from other low-lying atolls which have also been said to be threatened with evacuation due to sea-level rise. Tuvalu (Farbotko 2005; McCubbin, Smit and Pearce 2015) and Kiribati (Gaillard 2012) are particularly pertinent in that, similarly to the findings reported here, other issues dominate the climate change agenda locally. Notable among these other issues are day-to-day livelihood concerns, meaning that people are, understandably, less inclined to think about large-scale changes such as mass migration under the hazy future of climate change projections. Yet the view in Maldives differs from that in these other studies, since a large majority suggested that Maldives will need to move due to sealevel rise. The most likely reason is that respondents living in the capital generally have higher educational levels and greater exposure to external views.

Insert Table 5. 
Table 5: Respondents' opinions on Maldivians moving en masse in response to sea-level rise

\subsection{Determinants of migration patterns}

Respondents were asked about their intentions to move away from their home location and about their opinion on the "need to move" strategy. In the previous section, some descriptive statistics were presented. Here, the questions are addressed regarding (i) which factors stand behind their decision to move? and (ii) which factors might influence households' opinions that future outmigration is a necessary strategy to deal with the changes in the weather and climate? Both questions may be answered using binary outcome models, i.e. models with binary dependent variables. In this study, a standard logit model (logistic regression) is used. Out of the 347 respondents, 295 could be used for analysis, because of missing values for some explanatory variables in the remainder. The explanatory variables represent various socio-demographic characteristics of the respondents as well as their experiences with weather changes and perceptions of climate change. The results presented contain only the statistically significant variables.

As for the factors influencing household migration patterns, 159 respondents intended to migrate and 136 did not. Table 6 presents maximum likelihood estimates of the model where the dependent variable was based on the respondents' decisions (or intentions) to move away. As a measure of goodness of fit, the percentage of correctly classified cases was computed. The percentage of correctly classified cases (e.g. respondent answered "yes" and the model predicts "yes") is $68.3 \%$. This model is thus considerably better that a purely random model and all the identified factors have the power to discriminate between those who would like to migrate and those who would not.

\section{Insert Table 6.}

\section{Table 6: Model - Factors influencing migration patterns}

The signs of estimated regression coefficients in Table 6 indicate the direction of influence of the underlying variables. The probability to migrate increases with the maximum education level of household members, perhaps because more education exposes respondents' to different ideas, lessening the fear of other locations while increasing their curiosity. Additionally, many Maldivians leave their country for higher education and then return, meaning that they have ties and experience elsewhere, making it easier to contemplate again migration outside their country.

Social and environmental threats are important factors influencing decisions to migrate. Households facing higher social and environmental threats, or with increasing subjective perception of weather changes, are more likely to intend to migrate than those facing lower threat levels. Regarding the negative signs on the quadratic terms, these positive effects on probability to migrate are diminishing in both the mentioned cases. The positive coefficient on the last variable (indicating the respondents" opinion about the "need to move" strategy) suggests that the decision to migrate is tightly connected with their opinion about the "need to move" strategy. This result is important, demonstrating that views can translate into action, rather than people simply expressing an opinion with no intention of ever acting on it.

As for the factors determining opinion about the "need to move" strategy, 160 respondents agreed with "the need to move because of weather changes" and 135 respondents disagreed. The maximum likelihood estimates are presented in Table 7. This model is able to classify correctly $72.8 \%$ of observed cases. 


\section{Insert Table 7.}

\section{Table 7: Model - Factors influencing the opinion about "need to move" strategy}

From Table 7, it can be seen that households living longer in their place of residence tend to agree with the "need to move" strategy less than households living there for a shorter time period. Older respondents tend to agree with the strategy to out-migrate less than younger ones. In examining migration, an assumption is often that younger people are more adventurous and willing to accept change, so they would be predisposed towards migration more than the older generation. Yet the migration literature has long accepted and explored multiple reasons for older people wanting to move and deciding to migrate (e.g. Litwak and Longino 1987, Wiseman 1980). Out of the multitude of reasons for older people supporting migration, the Maldivians might be demonstrating an impetus of parents seeking better lives for their children and grandchildren especially given their worries about the future. Additionally, the older people have experienced more good times and more bad times than younger generations, giving the older people a reason to push for a better life. This discussion reaffirms the need for those exploring climate change migration to include more insights and understandings from the wider migration literature.

Regarding the quadratic term in Table 7, this negative effect is diminishing in absolute terms. To be more specific, the age of 45 represents the point where negative effects change for positive ones. The main possible explanations intersect with the many reasons for older people seeking to migrate (e.g. Litwak and Longino 1987, Wiseman 1980) such as moving to be with their children, wishing to be closer to good health care facilities, and decline in or loss of livelihoods. All three factors in Maldives tend to mean moving to Malé, which is where the questionnaire was implemented.

Further important factors in respondents' opinions on the overall necessity to migrate which emerged are negative experiences with environmental change and the apparent (or assumed) rise in resulting damage. As the results in Table 7 suggest, negative experiences increase the probability that the household will agree with the "need to move" strategy. This result is not surprising in that negative experiences would be expected to spur on a need for or interest in changing one's location. This finding conforms with evidence from wider literature showing that environmental trends with detrimental impacts can lead to migration choices, although many are left behind because they cannot afford to move or feel that they have no option of moving (Felli and Castree 2012; Foresight 2011). Respondents to this question in Maldives are demonstrating migration as adaptation to negative experiences with environmental change, seeking the advantages which the literature reports (Birk and Rasmussen 2014; Black et al. 2011a; Tacoli 2009).

Respondents knowing people who had moved away, but whose final destinations were unknown or to Asia tend to agree with the "need to move" strategy" more than those who know people who had moved elsewhere or who had stayed in Malé. According to the respondents, those moving to Europe, the UK, the USA, Australia, or New Zealand are moving there mostly for better education, or because they had already received better education and wished to use it to obtain better jobs. The decision to migrate to these countries may thus influence others regarding the need (or desirability) to move. This effect is found frequently in the mobilities literature, where non-migrants are more inclined to consider migration when they know someone who has left, and to prefer destinations where they know people already or where others have already lived (e.g. Bedford and Hugo 2012; Epstein and Gang 2006).

This behaviour has three important implications. First, educated young people deciding to migrate abroad will negatively influence the average educational level of the Maldivian labour force. Second, the older generation might choose to or feel obliged to follow the younger generation, to be with their children and grandchildren, as alluded to above. Third, the observed migration tendencies 
may result from positive migration experience of relatives or friends (see also Epstein and Gang 2006), not just perceived environmental reasons. These patterns match the patterns expressed in the migration and mobilities literature referenced throughout, indicating that climate change might not (yet) bring much which is new to the decision-making processes of Maldivians considering whether or not to migrate.

\section{Conclusion}

Although sea-level rise is a major projected climate change impact for Maldives and is perceived by Maldivians to be a concern, it is disputable if ongoing adaptation measures are sufficient to enable the country and its people to deal with its projected futures. Although a set of various adaptation measures is being considered and some are being implemented-such as sea walls, land reclamation, beach vegetation, relocation, warning systems, and whole-island elevation changesuncertainties about future climate change and its impacts remain. Even though it is not perceived or experienced as an everyday reality in and around Malé, the future climate change threat and outmigration option have, to some extent, become slowly rooted in people's minds - at least to the point where they consider it even if their migration-related motivations still remain with other factors.

Regarding migration as adaptation, contrary to Arnall and Kothari (2015), who seem to underestimate ordinary people's perceptions of climate change and find that they focus more on everyday livelihood challenges than on long-term solutions, a comparatively high proportion of our respondents was familiar with the potential necessity for out-migration and the possible climate change links. Yet awareness of these links and ability to discuss them do not necessarily directly influence actual opinions and decisions. The reason is that expressed views occur in the context that Maldivians are already migrating out of Maldives - and have long done so-without considering climate change. Reasons for migrating encompass education, health care, social position, politics, jobs, and livelihoods (Kelegema 2011; Kothari 2014; Sathiendrakumar and Tisdell 1987). This situation is not unique to Maldives, but occurs in many other small island states, with migration having been an important component of life and livelihoods since these islands were first settled (Bedford and Hugo 2012; Kelman et al. 2015; Le De et al. 2015; Rudiak-Gould 2013; Shen and Gemenne 2011; Stojanov et al. 2014).

Nevertheless, these findings do not imply that Maldivians see out-migration as an easy or desirable adaptation measure. As the results outlined above and the discussion show, other adaptation measures are considered and many would prefer to implement these first, rather than prioritising migration with respect to climate change. The ongoing efforts to implement development processes in Maldives (e.g. Alexander and Mercer 2012; MEEW 2007, van Alphen, Kekkert and van Sark 2008) demonstrate the efforts put into keeping the country viable for lives and livelihoods. This situation matches similar efforts in many other small island states where development work not related to climate change can continue in parallel with climate change adaptation measures, sometimes being complementary (e.g. for Seychelles, Mercer et al. 2014) and sometimes causing tensions (e.g. for Kiribati, Gaillard 2012).

Overall, it appears as if Maldives is aiming to adapt to projected climate change impacts with a combination of hard and soft measures, neither just implementing stop-gap measures nor abandoning the country (Elrick-Barr, Glavonic and Kay 2015; MEEW 2007; Republic of Maldives 2010; Sovacool 2012). Moreover, Maldivians in the capital area are reasonably well-informed and have a knowledge baseline covering ongoing and future climate change impacts, as well as possible responses to those impacts, of which migration is certainly an option. None of this significantly impacts Maldivians' views of or interests in migrating, but decisions will be based primarily on reasons other than climate change. 
Thus, migration as adaptation has traction among Maldivians in Malé, but is not considered to be a principal or desired option. This attitude matches two main threads in the "migration as adaptation" literature discussed in section 3.2. First, migration as adaptation is a viable option, and has advantages, but may often be implemented in conjunction with other measures. Second, migration as adaptation does not mean forced or involuntary migration, so those migrating would not wish to be labelled as "climate refugees" or "climate change refugees". Irrespective of the combination of adaptation measures ultimately adopted, they should not be implemented in a top-down fashion but, as suggested by Alexander and Mercer (2012), ordinary Maldivians must be included in wider discussions about future trajectories of their livelihoods and homeland.

\section{Acknowledgement}

We would like to express our gratitude to the anonymous respondents for their time and thoughts, and to the interviewers who patiently collected their answers.

\section{References}

Alexander B and Mercer J 2012 Eight Components of Integrated Community Based Risk Reduction: A Risk Identification Application in the Maldives Asian Journal of Environment and Disaster Management 4 57-82

Alscher S 2011 Environmental Degradation and Migration on Hispaniola Island International Migration 49 (Supplement) e164-e188

Arnall A and Kothari U 2015 Challenging climate change and migration discourse: Different understandings of timescale and temporality in the Maldives Global Environmental Change 31 199-206

Bailey R T Khalil A and Chatikavanij V 2015 Estimated current and future groundwater resources of the Maldives Journal of American Water Resources Association 51 112-122

Baldacchino G (ed) 2007 A World of Islands: An Island Studies Reader, Agenda Academic \& Institute of Island Studies, Malta and Canada.

Banerjee S. Black R. and Kniveton D. 2014 Migration as an effective mode of adaptation to climate change ICIMOD, Kathmandu (http://lib.icimod.org/record/29990)

Basu M and Shaw M 2013 Water policy, climate change and adaptation in South Asia. International Journal of Environmental Studies 70 175-191

Bedford R and Hugo G 2012 Population Movement in the Pacific: A Perspective on Future Prospects Department of Labour, Wellington

Bettini G 2013 Climate Barbarians at the Gate? A critique of apocalyptic narratives on 'climate refugees' Geoforum 45 63-72

Bettini G 2014 Climate migration as an adaption strategy: desecuritizing climate-induced migration or making the unruly governable? Critical Studies on Security 2 180-195

Birk T and Rasmussen K 2014 Migration from atolls as climate change adaptation: Current practices, barriers and options in Solomon Islands Natural Resource Forum 38 1-13

Black R Bennett S R G Thomas S M Beddington J R 2011a Migration as adaptation Nature 478 477-479

Black R Adger W N Arnell NW Dercon S Geddes A and Thomas D S G 2011b The effect of environmental change on human migration Global Environmental Change 21S S3-S11.

Cameron A C and Trivedi P K 2005 Microeconometrics. Cambridge University Press. 
De Sherbinin et al. 2011 Preparing for Resettlement Associated with Climate Change Science 334 456-457

Dolman A 1985 Paradise lost? The past performance and future prospects of small island developing countries in Dommen $\mathbf{E}$ and Hein $\mathbf{P}$ eds States, microstates and islands Croom Helm, London 40-69

Elrick-Barr C, Glavonic B C and Kay R 2015 A tale of two atoll nations: A comparison of risk, resilience and adaptive response of Kiribati and the Maldives in Glavonic B C Kelly M Kay $\mathbf{R}$ Travers A eds Climate Change and the Coast: Building Resilient Communities Taylor and Francis Group, CRC Press, NW 313-336

Epstein G S and I N Gang 2006 The Influence of Others on Migration Plans Review of Development Economics 10 652-665

Farbotko C 2005 Tuvalu and Climate Change: Constructions of Environmental Displacement in The Sydney Morning Herald. Geografiska Annaler: Series B, Human Geography 87 279-293

Felli R and Castree N 2012 Neoliberalising adaptation to environmental change: foresight or foreclosure? Environment and Planning A 44 1-4

Foresight 2011 Migration and global environmental change: final project report The Government Office for Science, London.

Fulu E 2007 Gender, Vulnerability, and the Experts: Responding to the Maldives Tsunami Development and Change 38 843-864

Fulu E 2014 Domestic Violence in Asia: Globalization, Gender and Islam in the Maldives Routledge, London

Gaillard JC 2007 Resilience of traditional societies in facing natural hazards. Disaster Prevention and Management 16 522-544.

Gaillard JC 2012 The climate gap. Climate and Development 4 261-264

GEF 2009 Integration of Climate Change Risks into the Maldives Safer Island Development Programme: Information about fund (http://www.apan-gan.net/adaptation-practices/integrationclimate-change-risks-maldives-safer-island-development-programme) Accessed 20 May 2015

Ghina F 2003 Sustainable development in small island developing states. The case of the Maldives Environment Development and Sustainability 5 139-165

Guan J and McElroy J L 2012 The Determinants of Migration in Small Islands Island Studies Journal 7 80-95

Hartmann B 2010 Rethinking climate refugees and climate conflict: rhetoric, reality and the politics of policy discourse Journal of International Development 22 233-246

Hay E J 2013 Small island developing states: coastal systems, global change and sustainability Sustainability Science 8 309-326

Henry S Schoumaker B and Beauchemin C 2004 The Impact of Rainfall on the First OutMigration: A Multi-level Event-History Analysis in Burkina Faso Population and Environment 25 423-460

Hugo G 2011 Future demographic change and its interactions with migration and climate change Global Environmental Change 21 S21-S33

Ibrahim M S A, Bari M R and Miles L 2002 Water resources management in Maldives with an emphasis on desalination

(http://www.pacificwater.org/userfiles/file/Case\%20Study\%20B\%20THEME\%201\%20Maldives\% 20on\%20 Desalination.pdf) Accessed 19 May 2015

IOM 2015 Assessing the Climate Change, Environmental Degradation and Migration Nexus in South Asia (https://environmentalmigration.iom.int/projects/assessing-climate-changeenvironmental-degradation-and-migration-nexus-south-asia) Accessed 19 January 2016

IPCC 2013-2014 Fifth Assessment Report Intergovernmental Panel on Climate Change, Geneva Islam F, Hove H and Parry J-E 2011 Review of current and planned adaptation action: South Asia International Institute for Sustainable Development 
Julca A and Paddison O 2010 Vulnerabilities and migration ins Small Islands Developing States in the context of climate change Natural Hazards 55 717-728

Kelegema S ed 2011 Migration, Remittances and Development in South Asia Sage, New Delhi Kelman I 2014 No change from climate change: vulnerability and small island developing states Geographical Journal 180 120-129

Kelman I 2015 Difficult decisions: Migration from Small Island Developing States under climate change Earth Future 3 133-142

Kelman I Stojanov R Khan S Gila OA Duží B and Vikhrov D 2015 Viewpoint paper. Islander mobilities: any change from climate change? International Journal of Global Warming 8 584-602 King D Bird D Haynes K Boon H Cottrell A Millar J Okada T Box P Keogh D Thomas M 2014 Voluntary relocation as an adaptation strategy to extreme weather events International Journal of Disaster Risk Reduction 8 83-90

King R and Connell J eds 1999 Small Worlds, Global Lives: Islands and Migration Island Studies Pinter, London.

Kothari U 2014 Political discourses of climate change and migration: resettlement policies in the Maldives The Geographical Journal 180 130-140

Kumar V 2014 Climate Change and the Future Governance of the Micro-Island States of the Indian Ocean Region. Associate Paper Future Directions International Pty Ltd., Dalkeith

Le De L Gaillard JC Friesen W Matautia Smith F 2015 Remittances in the face of disasters: a case study of rural Samoa Environment, Development and Sustainability 17 653-672

Lewis J 1999 Development in Disaster-prone Places: Studies of Vulnerability, Intermediate Technology Publications, London.

Lewis J 2009 An island characteristic: Derivative vulnerabilities to indigenous and exogenous hazards. Shima: The International Journal of Research into Island Cultures 3 3-15.

Litwak E, Longino Jr. C F. 1987 Migration Patterns Among the Elderly: A Developmental Perspective The Gerontologist 27 266-272

Martin M Billah M Siddiqui T Abrar C Black R and Kniveton D 2014 Climate-related migration in rural Bangladesh: a behavioural model Population and Environment 36 85-110 McCubbin S Smit B and Pearce T. 2015. Where does climate fit? Vulnerability to climate change in the context of multiple stressors in Funafuti, Tuvalu Global Environmental Change 30 43-55 McLeman R Smit B 2006 Migration as an adaptation to climate change. Climatic Change $7631-$ 53

McLeman R Hunter L M 2010 Migration in the context of vulnerability and adaptation to climate change: insights from analogues. WIREs Climate Change $1450-461$

MEEW 2007 National Adaptation Program for Action (NAPA). Republic of Maldives. Ministry of Environment, Energy and Water, Malé

MEE 2011 State of the Environment Maldives 2011. Ministry of Environment and Energy, The Republic of Maldives, Male

Mercer J Kurvits T Kelman I, and Mavrogenis S 2014. Ecosystem-Based Adaptation for Food

Security in the AIMS SIDS: Integrating External and Local Knowledge. Sustainability 6 5566-5597

MHAHE 2001 First National Communication of Maldives to the UNFCCC. Ministry of Home Affairs, Housing and Environment, Malé

Mimura N L Nurse R F McLean J Agard L Briguglio P Lefale Payet R and Sem G 2007 Small islands. Climate Change 2007: Impacts, Adaptation and Vulnerability in Parry M L Canziani O F Palutikof $\mathbf{J} \mathbf{P}$ van der Linden $\mathbf{P} \mathbf{J}$ and Hanson $\mathbf{C} \mathbf{E}$ eds Fourth Assessment Report of the Intergovernmental Panel on Climate Change Cambridge University Press, Cambridge, UK, p. 687716.

Myers N 1993 Environmental Refugees in a Globally Warmed World BioScience 43 752-761 Nicholson C T M 2014 Climate change and the politics of causal reasoning: the case of climate change and migration The Geographical Journal 180 151-160 
Pardasani M 2006 Tsunami reconstruction and redevelopment in the Maldives: A case study of community participation and social action Disaster Prevention and Management 15 79-91

Pernetta J C 1992 Impacts of climate change and sea-level rise on small island states. National and international responses Global Environmental Change 2 19-31

Pernetta J and Sestini G 1989 The Maldives and impacts of expected climate changes UNEP Regional Seas Report No. 104

Piguet E 2008 Climate change and forced migration. New Issues in Refugee Research, Research Paper No. 153. United Nations High Commissioner for Refugees, Geneva.

Rain D 1999 Eaters of the Dry Season: Circular Labour Migration in the West African Sahel. Boulder, CO: Westview Press

Republic of Maldives 2010 Strategic National Action Plan for Disaster Risk Reduction and Climate Change Adaptation 2010-2020 (www.unisdr-

apps.net/confluence/download/attachments/9110285/snap-Maldives.pdf) Accessed 15 May 2015

Rudiak-Gould P 2013 Climate Change and Tradition in a Small Island State: The Rising Tide Routledge, Abingdon

Sathiendrakumar R 1996 Problems Faced by Indian Ocean Island Economies: The Case of the Maldives in Gabbay R, Gosh R N and Siddique M A B eds Economics of Small Island Nations New Age International Ltd.,University of Western Australia and the International Institute for Development Studies, New Delhi

Sathiendrakumar R and Tisdell C A 1987 Migration from Traditional Rural Communities and Outside Employment: A Study of Maldivian Fishing Villages The South East Asian Economic Review 8 121-163

Shaig A 2006 Climate Change Vulnerability and Adaptation Assessment of the Maldives Land and Beaches of Maldives, Technical Papers to Maldives National Adaptation Plan of Action for Climate Change Ministry of Environment, Energy and Water, Malé

Shen S Gemenne F 2011 Contrasted Views on Environmental Change and Migration: the Case of Tuvaluan Migration to New Zealand International Migration 49 e224-e242

Sovacool B J 2012 Expert views on climate change adaptation in the Maldives Climatic Change 114 295-300

Spillius J 1957 Natural Disaster and Political Crisis in a Polynesian Society: An Exploration of Operational Research Human Relations 10 3-27.

Stojanov R Kelman I. Shen S. Duží B Upadhyay H Vikhrov D Lingaraj G J and Mishra A 2014 Contextualising Typologies of Environmentally Induced Population Movement Disaster Prevention and Management 23 508-523

Tacoli C 2009 Crisis or adaptation? Migration and climate change in a context of high mobility Environment and Urbanization 21 513-525

Upadhyay H Kelman I Lingaraj GJ Mishra A Shreve CM Stojanov R 2015 Conceptualizing and Contextualizing Research and Policy for Links between Climate Change and Migration International Journal of Climate Change Strategies and Management 7 394-417

van Alphen K Hekkert M P and van Sark W G H J M 2008 Renewable energy technologies in the Maldives - Realizing the potential Renewable and Sustainable Energy Reviews 12 162-180

Wiseman R F 1980 Why Older People Move: Theoretical Issues Research on Aging 2: 141

World Bank 2007 Country Assistance Strategy for the Republic of Maldives Report No. 41400 MV. FY08 - FY12, World Bank Group, Washington, D.C.

World Bank 2010 Climate Change in the Maldives (http://go.worldbank.org/3RJ8PGGSM0)

Accessed 20 January 2016

World Bank 2014 Maldives - Development update.

(http://documents.worldbank.org/curated/en/2014/04/19402100/maldives-development-update)

Accessed 10 June 2015

World Bank 2015 Central Government Debt: Maldives. 
(http://data.worldbank.org/indicator/GC.DOD.TOTL.GD.ZS/countries) Accessed 20 May 2015 WTTC 2014 Travel \& Tourism Economic Impact 2014 Maldives. World Travel \& Tourism Council (http://www.wttc.org//media/files/reports/economic\%20impact\%20research/country\%20reports/maldives2014.pdf) Accessed 30 June 2016 
Table 1: Examples of hard and soft adaptation measures for coasts

\begin{tabular}{lll}
\multicolumn{1}{c}{\begin{tabular}{c}
\multicolumn{1}{c}{$\begin{array}{c}\text { Climate change } \\
\text { impact }\end{array}$} \\
Sea-level rise
\end{tabular}} & \multicolumn{1}{c}{ Hard measure } & \multicolumn{1}{c}{ Soft measure } \\
& $\begin{array}{l}\text { Construction of sea walls and } \\
\text { tetra pods. }\end{array}$ & $\begin{array}{l}\text { Mangrove afforestation and beach } \\
\text { nourishment. }\end{array}$ \\
\hline Water scarcity & Desalinization of water & Capturing rainwater \\
\hline Saltwater intrusion & $\begin{array}{l}\text { Elevated water tanks and storage } \\
\text { systems }\end{array}$ & Thickening coastal vegetation \\
\hline Tidal inundation & Land reclamation & Dune replenishment \\
\hline Community relocation & $\begin{array}{l}\text { Construction of artificial or } \\
\text { designer islands }\end{array}$ & $\begin{array}{l}\text { Coral propagation and protection } \\
\text { around existing islands }\end{array}$ \\
\hline
\end{tabular}

Source: Adapted from Sovacool (2012). 
Table 2: Respondents' perceptions of challenges

\section{Challenges \\ Relative frequency}

\begin{tabular}{lr}
\hline 0. Not able to specify any challenges & $10.09 \%$ \\
\hline 1. Environmental change & $37.18 \%$ \\
\hline - sea-level rise and soil erosion & $7.20 \%$ \\
\hline - lack of space and population growth & $17.87 \%$ \\
\hline - dry weather and water shortage & $3.75 \%$ \\
\hline - climate variability & $5.48 \%$ \\
\hline - pollution of environment & $2.88 \%$ \\
\hline 2. Job availability & $10.37 \%$ \\
\hline 3. Higher crime rates & $3.75 \%$ \\
\hline 4. Political instability, conflicts & $4.61 \%$ \\
\hline 5. Low quality of health care and education & $4.03 \%$ \\
\hline 6. Others & $29.97 \%$ \\
\hline
\end{tabular}


Table 3: Preferred migration destinations by destination cluster and education level

\begin{tabular}{|c|c|c|c|}
\hline Destination & $\begin{array}{c}\text { Total } \\
\text { (percentage) }\end{array}$ & $\begin{array}{c}\text { Secondary and higher } \\
\text { education* } \\
\text { (percentage) }\end{array}$ & $\begin{array}{c}\text { University education*** } \\
\text { (percentage) }\end{array}$ \\
\hline Unknown & $25.68 \%$ & $25.61 \%$ & $27.63 \%$ \\
\hline Anywhere & $18.58 \%$ & $15.85 \%$ & $23.68 \%$ \\
\hline Cluster 1: Europe, USA & $8.74 \%$ & $7.32 \%$ & $7.89 \%$ \\
\hline France & $1.09 \%$ & $1.22 \%$ & $1.32 \%$ \\
\hline Germany & $1.09 \%$ & $1.22 \%$ & $1.32 \%$ \\
\hline Ireland & $0.55 \%$ & $0.00 \%$ & $0.00 \%$ \\
\hline Russia & $1.09 \%$ & $2.44 \%$ & $0.00 \%$ \\
\hline Switzerland & $0.55 \%$ & $0.00 \%$ & $0.00 \%$ \\
\hline $\begin{array}{l}\text { United } \\
\text { Kingdom } \\
\end{array}$ & $2.73 \%$ & $1.22 \%$ & $2.63 \%$ \\
\hline USA & $1.09 \%$ & $1.22 \%$ & $0.00 \%$ \\
\hline Cluster 2: Asia & $19.67 \%$ & $19.51 \%$ & $22.37 \%$ \\
\hline India & $3.28 \%$ & $3.66 \%$ & $2.63 \%$ \\
\hline Malaysia & $8.20 \%$ & $8.54 \%$ & $9.21 \%$ \\
\hline Qatar & $0.55 \%$ & $0.00 \%$ & $1.32 \%$ \\
\hline Singapore & $2.73 \%$ & $2.44 \%$ & $3.95 \%$ \\
\hline Sri Lanka & $3.83 \%$ & $3.66 \%$ & $3.95 \%$ \\
\hline Turkey & $0.55 \%$ & $1.22 \%$ & $0.00 \%$ \\
\hline $\begin{array}{l}\text { Cluster 3: Australia, New } \\
\text { Zealand }\end{array}$ & $18.58 \%$ & $17.07 \%$ & $18.42 \%$ \\
\hline Australia & $16.94 \%$ & $14.63 \%$ & $17.11 \%$ \\
\hline New Zealand & $1.64 \%$ & $2.44 \%$ & $1.32 \%$ \\
\hline Cluster 4: Maldives & $14.21 \%$ & $21.95 \%$ & $10.53 \%$ \\
\hline TOTAL (respondents) & 183 & 82 & 76 \\
\hline
\end{tabular}

Notes: Percentages are computed from the ratio of respondents preferring the corresponding destination Cluster to the total of all respondents intending to migrate (column 2), or the sub-totals with different education levels in columns 3 and 4. Column totals do not sum to $100 \%$ because multiple responses were allowed.

* Households with at least one member with a college diploma

** Households with at least one member with a bachelor degree or higher 
Table 4: Reasons for migrating according to destination cluster

\begin{tabular}{lcccccc}
\hline \multicolumn{1}{c}{ Reasons } & Unknown & Anywhere & $\begin{array}{c}\text { Cluster 1: } \\
\text { Europe, } \\
\text { USA }\end{array}$ & $\begin{array}{c}\text { Cluster } \\
\text { 2: Asia }\end{array}$ & $\begin{array}{c}\text { Cluster 3: } \\
\text { Australia, } \\
\text { New Zealand }\end{array}$ & $\begin{array}{c}\text { Cluster 4: } \\
\text { Maldives }\end{array}$ \\
\hline $\begin{array}{l}\text { Better education, } \\
\text { livelihoods, and } \\
\text { living conditions }\end{array}$ & $44.68 \%$ & $79.41 \%$ & $87.50 \%$ & $69.44 \%$ & $61.76 \%$ & $26.92 \%$ \\
$\begin{array}{l}\text { Environmental } \\
\text { conditions, disasters } \\
\text { and sea-level rise }\end{array}$ & $31.91 \%$ & $23.53 \%$ & $0.00 \%$ & $11.11 \%$ & $50.00 \%$ & $15.38 \%$ \\
\hline $\begin{array}{l}\text { Other } \\
\text { Total (respondents) }\end{array}$ & $40.43 \%$ & $14.71 \%$ & $12.50 \%$ & $27.78 \%$ & $26.47 \%$ & $61.54 \%$ \\
\hline
\end{tabular}

Note: Percentages are computed from the ratio of respondents mentioned the corresponding reason to the total of all respondents preferring the corresponding destination Cluster. Column totals do not sum to $100 \%$ because multiple responses were allowed. 
Table 5: Respondents' opinions on Maldivians moving en masse in response to sea-level rise

\begin{tabular}{lcc}
\hline \multicolumn{1}{c}{ Respondents' opinions } & Frequency & Percentages \\
\hline Do not know & 21 & $6.05 \%$ \\
\hline Yes, agree, we will have to move & 166 & $47.84 \%$ \\
\hline Not now, but perhaps in the future & 11 & $3.17 \%$ \\
\hline $\begin{array}{l}\text { Yes, some islands, but not Maldives } \\
\text { as whole }\end{array}$ & 2 & $0.58 \%$ \\
\hline No, disagree, do not believe & 61 & $17.58 \%$ \\
\hline It is necessary to adapt & 18 & $5.19 \%$ \\
\hline Indecisive & 3 & $0.87 \%$ \\
\hline No answer & 65 & $18.72 \%$ \\
\hline TOTAL & 347 & $100.00 \%$ \\
\hline
\end{tabular}


Table 6: Model - Factors influencing migration patterns

\begin{tabular}{lccc}
\hline Variable & $\begin{array}{c}\text { Parameter } \\
\text { estimate }\end{array}$ & $\begin{array}{c}\text { Standard } \\
\text { error }\end{array}$ & p-value \\
\hline Intercept & -3.7159 & 1.2248 & 0.0024 \\
\hline $\mathrm{X}_{1}$ & 0.2493 & 0.145 & 0.0856 \\
\hline $\mathrm{X}_{2}$ & 0.2092 & 0.1009 & 0.038 \\
\hline $\mathrm{X}_{2}$ squared & -0.00441 & 0.00254 & 0.0829 \\
\hline $\mathrm{X}_{3}$ & 0.1537 & 0.1832 & 0.4015 \\
\hline $\mathrm{X}_{3}$ squared & -0.0402 & 0.0274 & 0.1423 \\
\hline $\mathrm{X}_{4}$ & 1.0197 & 0.252 & 0.0000
\end{tabular}

Notes: p-values are based on the Wald chi-squared test statistics for the hypothesis test that an individual predictor's regression coefficient is zero given the rest of the predictors in the model. The variables were selected using a stepwise regression approach with probabilities (p-values) 0.3 to enter into the model and 0.15 to stay in the model. Statistical significance of squared variables was evaluated jointly with the significance of the corresponding level (non-squared) variable. The dependent variable takes a value of 1 if the respondent intended to move away and 0 if not. Statistically significant variables are:

$\mathrm{X}_{1}=$ maximum educational level of the household members $(1$ - illiterate, 2 - can read and write, 3 elementary school, 4 - secondary school, 5 - high school, 6 - bachelor degree or higher).

$\mathrm{X}_{2}=$ variable expressing the evaluation of social and environmental living conditions computed as the sum on subjective scale (from 1 - OK, no danger, across 3 - middle threat, to 5 - the worst, with 2 and 4 representing values in between) for 6 categories: crime, air pollution, rubbish outside, lack of potable water, dirty sea water, and the environment generally.

$\mathrm{X}_{3}=$ variable expressing the number of weather changes that were noticed by the respondent. It is based on the sum of the number of answers "yes" to particular changes in the wet season (summer monsoons) and the dry season (in winter) These particular changes included options that summer monsoons and the winter dry season are coming sooner or later; that they are hotter or colder; and that there is more rain or less rain.

$\mathrm{X}_{4}=$ dummy variable expressing the respondent's opinion about the "need to move" strategy. This variable equals 1 where the household agreed with the need to move and equals 0 otherwise. 
Table 7: Model - Factors influencing the opinion about "need to move" strategy

\begin{tabular}{lccc}
\hline Variable & $\begin{array}{c}\text { Parameter } \\
\text { estimate }\end{array}$ & $\begin{array}{c}\text { Standard } \\
\text { error }\end{array}$ & p-value \\
\hline Intercept & 1.2214 & 1.0558 & 0.2473 \\
\hline $\mathrm{X}_{1}$ & -0.0244 & 0.0106 & 0.0206 \\
\hline $\mathrm{X}_{2}$ & -0.1107 & 0.0605 & 0.0672 \\
\hline $\mathrm{X}_{2}$ squared & 0.00122 & 0.000803 & 0.1288 \\
\hline $\mathrm{X}_{3}$ & -1.9829 & 1.1538 & 0.0857 \\
\hline $\mathrm{X}_{4}$ & 0.8663 & 0.282 & 0.0021 \\
\hline $\mathrm{X}_{5}$ & -0.6324 & 0.3966 & 0.1108 \\
\hline $\mathrm{X}_{6}$ & 0.8039 & 0.3288 & 0.0145 \\
\hline $\mathrm{X}_{7}$ & 0.5389 & 0.3153 & 0.0874 \\
\hline $\mathrm{X}_{8}$ & 0.0267 & 0.0101 & 0.0084
\end{tabular}

Notes: model fitting procedures are as defined in the caption to Table 6 . Statistically significant variables were:

$\mathrm{X}_{1}=$ number of years the respondent has been living at his or her place of residence.

$\mathrm{X}_{2}=$ age of the respondent.

$\mathrm{X}_{3}=$ dummy variable equals 1 if the respondent comes from abroad, and 0 otherwise (the basic category is the respondent coming from other places than abroad).

$\mathrm{X}_{4}=$ dummy variable defined using the answers to the question "do you intend to move away?". It equals 1 if the answer is "yes" and zero otherwise.

$\mathrm{X}_{5}=$ dummy variable equals 1 if the household intends to move away but does not know where and 0 otherwise (the basic category is households knowing the destination where to move or intending not to move).

$\mathrm{X}_{6}=$ dummy variable equals 1 if the household knows the people who had moved away but the destination was unknown and 0 otherwise (the basic category is households knowing the people who had moved to Europe, USA, UK, Australia or New Zealand, or elsewhere in Malé).

$\mathrm{X}_{7}=$ dummy variable equals 1 if the household knows people who had moved away and their destination was Asia and 0 otherwise (the basic category is households knowing people who had moved to Europe, USA, UK, Australia or New Zealand, or elsewhere in Malé).

$\mathrm{X}_{8}=$ variable expressing the level of negative environmental changes around the place where the lives. It is computed as a sum of level of damages (on a scale from 1 - OK, no danger, across 3 - middle threat, to 5 the worst, with 2 and 4 representing values in between) experienced by the respondent connected with 11 kinds of changes (number of trees, fisheries, rapid urbanization, sea water pollution, lack of drinking water, factory-based industry, air pollution, destruction of nature, rapid increase in the amount of tourists, beach erosion, other disturbances). 